\title{
Ice Silk Road: Assessment of the Current State and Development Prospects
}

\author{
Lyubov Vasilievna Larchenko \\ Herzen University \\ Saint Petersburg, Russia \\ lubalar@mail.ru
}

\begin{abstract}
The Ice Silk Road, one of the routes of the New Silk Road project, is being actively developed by Russia and China. The most important part of the Ice Silk Road is the Northern Sea Route. The article considers the interests of Russia and China and shows that in creating the Ice Silk Road, the interests of Russia and China coincide as much as possible. In order to find out whether the route along the Ice Silk Road is advantageous, a comparative analysis with the traditional sea route through the Suez Canal was carried out. It has been concluded that for a number of positions the Ice Silk Road is a more profitable route. The transformation of the Ice Silk Road into a route open on a global scale depends on a number of reasons. The article emphasizes that the creation of the Ice Silk Road is not an attempt to replace the traditional route, but an opportunity for economic cooperation between the countries of the Pacific coast, and especially in the development of Arctic oil and gas resources. The interests of other countries to this project are considered as well. The joint projects on the route of the Ice Silk Road and the prospects for the development of this route are analyzed.
\end{abstract}

Keywords: Ice Silk Road, Northern Sea Route, China, Russia, economic interests, cooperation

\section{INTRODUCTION}

In recent years, worldwide interest is drawn to the New Silk Road project, which consists of two projects, the Silk Road Economic Belt and the 21st Century Sea Silk Road. China sets the task of connecting the economically developed countries of East Asia and Europe along two ancient routes of the Silk Road. It is planned to create an extensive infrastructure along the Silk Road route from the western borders of China through the countries of Central Asia and Iran to Europe.

At present, Russia and China are actively developing the third route - the Ice Silk Road (ISP), the most important part of which should be the Northern Sea Route (NSR).

In many ways, the idea of creating the Ice Silk Road is explained by the fact that in recent years, interest in the development of the Arctic has sharply increased throughout the world. What are the reasons?
- Firstly, it is connected with the resource potential and transport significance of the Arctic;

- Secondly, this is the lack of recognized and normatively formalized demarcation of the international northern sea borders and the Arctic shelf;

- Thirdly, the ice in the Arctic is melting, which means that the transport and resource use of the Arctic is becoming more accessible.

Another explosion of interest came after the US Geological Survey published a map of potential hydrocarbon reserves in the Arctic. According to scientists, more than a quarter of the world's hydrocarbon reserves occur in the Arctic zone. Moreover, presumably, the largest reserves of oil and gas lie in the Russian sector of the Arctic.

Recently, not only political, informational and organizational preparation of the project is carried out, but significant funds are already being invested in the development of NSR, as part of the ISR. However, there are many challenges remain in building the ISR. This refers to investments and technical equipment of the route, and the geopolitical situation. Only by solving emerging problems and finding a balance of interests is it possible to successfully solve the problem.

\section{LITERATURE REVIEW AND RESEARCH METHODS}

In order to analyze the situation in the article the studies of domestic and foreign scientists on the problems of creating the Ice Silk Road, projects under construction and planned for construction on this route are used $[1,2,3,4,5,6]$.

In the study the following research methods were used: economic-statistical method; economic-geographical method; comparative analytical; expert evaluations; balance method. The empirical and information base, in addition to special literary sources and periodicals, the official statistics of the State Committee on Statistics of the Russian Federation, official data of the Ministry of Transport of the Russian Federation, materials of large Russian oil and gas companies were used (Gazprom, Rosneft, Novatek and others). 


\section{RESULTS}

\section{A. Coordination of interests of Russia and China}

In building the ISR, the interests of Russia and China coincide as much as possible. All other directions, including the Central Asian or sea routes of the Silk Road, are less interesting for the Russian Federation.

Russia's interests in the implementation of the Ice Silk Road project are the following:

- It is important for Russia to develop NSR, however, in modern conditions, the creation of infrastructure and ice-class vessels requires large investments that China has, being interested in developing ISR;

- Under the conditions of sanctions, Russia needs new technologies and equipment for the development of the Arctic and the development of NSR;

- The construction of the ISR will provide an opportunity to develop more actively mineral deposits and, mainly, oil and gas resources in the Arctic;

- Against the backdrop of difficult relations with the West, Russia is currently interested in strengthening and expanding cooperation with China. Large joint projects are the most reliable way to build a long-term partnership.

In the development of the Arctic, China can provide Russia with technical support in various fields. For example, deliveries of drilling machines made by the Chinese company Honghua for the construction of an LNG regasification terminal in Yamal. Machinery and equipment operate reliably in $-45^{\circ} \mathrm{C}$ and a squally wind above 12 points. Chinese enterprises are currently building 6 transport vessels and are responsible for the operational activities of 14 of the 15 gas tankers [7].

The main interests of China in creating the ISR are the following:

- This is the shortest and safest sea route from China to Europe;

- The development of the route makes it possible to mitigate the problem of insufficient gas supply in China;

- Many Chinese enterprises working in the fields of energy, shipbuilding, finance, transport, etc.;

- China is interested in projects for the development of Arctic energy resources located in the ISR zone.

\section{B. Northern Sea Route as the most important part of the Ice Silk Road}

The Northern Sea Route is the shortest sea route between the European and Asian parts of Russia, between Asia and Europe. This is an essential part of LSP. It provides normal living conditions for local population throughout the northern regions. In addition, the NSR passes through the territory, which is a strategic resource base, transports and exports natural resources extracted here, and by all that NSR ensures the solution of the most important tasks of Russia's socioeconomic development. The NSR is not only the Russian maritime transport communication and the main shipping route of Russia in the Arctic, but also the shortest sea route between the ports of Europe and Asia.

The NSR is more often compared with the traditional sea route through the Suez Canal, or, as it is also called, the Southern Sea Route (SSR). An example, which is cited in many sources to compare the duration of the NSR and SSR routes, is the path Rotterdam (Norway) - Yokohama (Japan), where the distance when using the Southern Sea Route will be 11205 nautical miles, and when using the Northern Sea Route - 7345 nautical miles $[8,9,10]$.

At first glance, a rather attractive direction for investment and the development of NSR is taking a shape. But is transit along the Northern Sea Route really beneficial, and what can it give to the country? In order to give an answer to this question, we will analyze the advantages and disadvantages of each of the routes (Table I). 
TABLE I. ADVANTAGES AND DISADVANTAGES OF THE SOUTHERN AND NORTHERN SEA ROUTES

\begin{tabular}{|c|c|c|}
\hline & Advantages of the route & $\begin{array}{c}\text { Disadvantages of the } \\
\text { route }\end{array}$ \\
\hline $\begin{array}{c}\text { Southern } \\
\text { Sea } \\
\text { Route } \\
\text { (via the } \\
\text { Suez } \\
\text { Canal) }\end{array}$ & $\begin{array}{l}\text { - Sustainable trade relations, } \\
\text { the presence of large ports } \\
\text { along the route, developed } \\
\text { infrastructure, etc. } \\
\text { - Egypt pursues an active } \\
\text { policy of investing in the } \\
\text { development of the Suez } \\
\text { Canal: in } 2015 \text {, the second line } \\
\text { of the Suez Canal was opened, } \\
\text { built in just a year (this } \\
\text { allowed to reduce the waiting } \\
\text { time for the passage from } 10- \\
12 \text { to } 3-4 \text { hours). } \\
\text { - Preferred route for the } \\
\text { transport of dangerous cargoes } \\
\text { such as petroleum products, } \\
\text { gas condensate, liquefied } \\
\text { natural gas, etc. }\end{array}$ & $\begin{array}{l}\text { - Due to the increase in } \\
\text { fees for passing through } \\
\text { the Suez Canal and a sharp } \\
\text { drop in the cost of fuel, it } \\
\text { is cheaper for ships to go } \\
\text { around Africa. In the } \\
\text { period from October to the } \\
\text { end of } 2015 \text { alone, more } \\
\text { than } 100 \text { vessels chose to } \\
\text { bypass Africa. } \\
\text { - Additional costs due to } \\
\text { piracy are } \$ 100-200 \\
\text { without insurance } \\
\text { payments and } \$ 220-250 \\
\text { thousand with it. } \\
\text { - Extremely unstable } \\
\text { situation in Egypt, which } \\
\text { many companies equate to } \\
\text { medium-term risks }\end{array}$ \\
\hline $\begin{array}{c}\text { Northern } \\
\text { Sea } \\
\text { Route }\end{array}$ & $\begin{array}{l}\text { - NSR is defined as the new } \\
\text { Ice Silk Road. China's } \\
\text { economic support could be one } \\
\text { of the key factors for the future } \\
\text { successful development of } \\
\text { NSR. } \\
\text { - For the Russian Federation, } \\
\text { the Arctic is a priority for the } \\
\text { implementation of state } \\
\text { programs for the development } \\
\text { of strategic territories. The } \\
\text { total amount of financing is } \\
\text { more than 220 billion rubles } \\
\text { for 2010-2020. One of the } \\
\text { financing priorities is the } \\
\text { restoration of transport } \\
\text { infrastructure and the } \\
\text { construction of a new } \\
\text { icebreaker fleet to expand the } \\
\text { possibilities of using NSR. } \\
\text { - Melting ice in the Arctic will } \\
\text { contribute to a longer } \\
\text { navigation time, and, therefore, } \\
\text { year-round attraction for } \\
\text { foreign vessels. } \\
\text { - When using NSR, due to the } \\
\text { gain in time and distance, the } \\
\text { cost of oil products and freight } \\
\text { cost are reduced, the size of the } \\
\text { insurance premium is reduced. } \\
\text { - In the structure of transported } \\
\text { cargoes, liquid bulk cargoes } \\
\text { now prevail. However, in the } \\
\text { future we can expect the } \\
\text { prevalence of such cargoes as } \\
\text { fish, coal, LNG in the east- } \\
\text { west direction, and in the west- } \\
\text { east direction - the } \\
\text { predominance of crude oil, } \\
\text { LNG, iron ore concentrate. }\end{array}$ & $\begin{array}{l}\text { - The current state of NSR } \\
\text { infrastructure contributes } \\
\text { to a high level of risk and, } \\
\text { consequently, a high level } \\
\text { of insurance rates. } \\
\text { - Container transportation } \\
\text { is considered as } \\
\text { unpromising, as it requires } \\
\text { an accurate schedule, } \\
\text { which in Arctic weather } \\
\text { conditions is not always } \\
\text { feasible from a technical } \\
\text { point of view. } \\
\text { - Significant investments } \\
\text { are needed in } \\
\text { infrastructure, the } \\
\text { development of the quality } \\
\text { of service, changes in the } \\
\text { tariff policy, an increase in } \\
\text { the number of icebreaker } \\
\text { ships. the bottom, } \\
\text { - The underdevelopment } \\
\text { of the NSR information } \\
\text { infrastructure, } \\
\text { includes monitoring, ship } \\
\text { traffic coordination, timely } \\
\text { information support for } \\
\text { crews, which is one of the } \\
\text { main factors taken into } \\
\text { account by foreign } \\
\text { companies } \\
\text { - Underdevelopment of } \\
\text { multimodal infrastructure } \\
\text { complexes at the junction } \\
\text { of the logistics routes of } \\
\text { various modes } \\
\text { transport. } \\
\text { - Large funds are needed } \\
\text { for additional exploration } \\
\text { of the } \\
\text { development of route } \\
\text { options, updating existing } \\
\text { maps. }\end{array}$ \\
\hline
\end{tabular}

The table shows that not everything is so univocal. There are a lot of cos and pros when comparing two trade sea routes. Currently, NSR is mainly a domestic Russian highway, along which there is an export of raw materials and supplying the northern territories with various cargoes [11]. International transport accounts for only $2 \%$.

The transformation of ISR into a global route depends on a number of reasons. Much will depend on global warming, which will allow navigation in arctic waters for a longer period of time. But the dependence on the cost of energy, especially oil, is great. On conditions when the oil price is kept low for ISR with its competitive advantage of shorter distance it will be much more difficult to compete with such a giant as the Southern Sea Route through the Suez Canal [12]. However, ISR has sufficient potential. On condition of successful development of its competitive advantages, it can, if not to overtake the Southern Sea Route through the Suez Canal, but at least press it out so that a number of cargoes which pass across the Indian Ocean from Southeast Asia to Europe and back, would be pulled to the northern direction [13].

For a more reasonable conclusion about the advantages of these sea routes, the economic component of the transportation of cargoes from Rotterdam to Yokohama by the ISR and the SSR was analyzed, which represents the ratio of time and financial costs. An economic analysis showed that the ISR is not only shorter, but also cheaper. Due to the shorter route, there is a saving on fuel, on staff remuneration, on reducing the cost of the vessel's freight. In addition, in the case of ISR, there is no payment for the passage of the vessel; there are no queues (as is the case with the Suez Canal); there is no risk of pirate attacks.

However, all positive aspects can be leveled due to negative factors: the risks are too great because of the large depreciation of the fixed assets of the port economy, the increasing likelihood of refusing to provide icebreaking support, bureaucratization of the permit procedure, etc. [14]. It should also be noted that NSR is the preferred option for ships with certain technical parameters, for example, enhanced measures of protection against ice and hummocks, as a result of which ships more expensive in terms of equipment are required, that makes NSR unattractive in the eyes of potential comers. The benefits of reduced time, distance, and costs when navigating ships on the NSR are leveled by existing weaknesses.

However, we need to understand that the ISR is not an attempt to replace the SSR, it is an opportunity for economic cooperation between the countries of the Pacific coast, and especially in the sphere of development of oil and gas resources in the Arctic.

NSR is currently working on a new transit facility from late July to November. A powerful icebreaker fleet is required for year-round use of the NSR. The icebreaker fleet of the USSR was not only the most powerful, but also had no equal in the world. At present, the nuclear icebreaker fleet has four icebreakers. However, almost all of these icebreakers, even taking into account the extension of their working life will be decommissioned in 4-5 years, therefore, the nuclear icebreaker fleet is being replaced. Three atomic icebreakers have already been launched: The Arctic, The Siberia and The Urals. Moreover, The Siberia has a two-draught design. This means 
liquefied natural gas in the Asia-Pacific region on the basis of the transshipment terminal [20].

Zvezda shipbuilding complex is being created in the Far East, which will become the largest shipyard in Russia. Here, China and Russia jointly finance the construction of ice-class cargo ships for the development of the Ice Silk Road project.

Taking into account the natural and living conditions of the Arctic zone, special attention should be paid to the selection of support ports throughout the ISR. The Ministry of Transport has prepared six key seaports that should provide freight traffic - Dikson, Dudinka, Murmansk, Pevek, PetropavlovskKamchatsky and Sabetta [21].

Nordic countries show great interest in ISR. They put forward the Arctic Corridor plan, which involves the construction of a railway from the depths of Europe to the port of Kirkenes, Norway, where the Ice Silk Road begins. You can also involve countries located outside the Arctic zone to participate in the creation of the ISR. For example, Japan and South Korea today have clear advantages in shipbuilding [22, 23].

\section{CONCLUSION}

Summing up the above, it can be stated that, despite the obvious difficulties, there is considerable interest in the world in the ISR project, which is actively being developed jointly by China and Russia. The difficult political situation in the world today contributes to the creation of such a global competitive transport artery that will serve both the political and economic interests of both countries. Russia and China have not only a desire, but much is already being done to develop ISR to the level of a competitive international highway. However, to be competitive, significant investments are required, and mainly, in the development of ports and the icebreaker fleet in order to meet modern world standards. Russia is developing the infrastructure of the North, creating nuclear-powered icebreakers based on the latest technologies, China is investing in projects on the ISR route, in the construction of cargo ships of an increased ice class. It should be noted the increasing role of such a factor as global warming, which is fundamental for increasing the period of navigation in this direction.

The geopolitical struggle for the Arctic is constantly escalating, especially between countries belonging to the Arctic region. It is likely that sanctions pressure on Russia will increase, and this could have a negative impact on the joint construction of the Ice Silk Road. However, Russia wants to reserve the right to the NSR as part of the ISR. The Russian Federation must ensure the normal operation of the NSR in the national interest and in the interests of national security.

\section{REFERENCES}

[1] A. A. Prianikova, A. F. Akhmadieva, and A. Y. Khrustaleva, "Evaluation of the Waste Processing System in the Concept of Management of the Sustainable Development of the Arctic Zone of the Russia", Proceedings of the 2018 IEEE International Conference and 
[13] "Arkticheskii potentsial. Severnyi morskoi put kak draiver ekonomicheskogo rosta" Peterburgskii mezhdunarodnyi ekonomicheskii forum, 2018 [Electronic resource]. Available at: http://roscongress.rbc.ru/arctic.

[14] A. V. Filatov, "Sozdanie effektivnoi sistemy dostavki gruzov v Arktike", Sbornik dokladov foruma Arktika nastoiashchee i budushchee, SPb, 4-6 December, 2017, pp. 27-29.

[15] "TSKB Aisberg ne iskliuchaet stroitelstva v Rossii eshche chetyrekh atomnykh ledokolov" [Electronic resource]. Available at: http://tass.ru/ekonomika/5410638.

[16] L. V. Larchenko and R. A. Kolesnikov, "The Development of the Russian Oil and Gaz Industry in Terms of Sanctions and Falling Oil Pric.", The Development of the Russian Oil and Gaz In-dustry in Terms of Sanctions and Falling Oil Pric, International Journal of Energy Econom-ics and Policy (IJEEP), 2017, vol. 7, no. 2, pp. 352-359.

[17] T. Demin, "Ledovyi shelkovyi put potentsialnye vozmozhnosti i problemy na puti ego razvitiia", Sbornik dokladov foruma Arktika nastoiashchee i budushchee, SPb, 4-6 December 2017, pp. 27-27.

[18] I. Van, "Rossiia - vazhnyi strategicheskii partner Kitaia po initsiative sozdaniia Poiasa i Puti" [Electronic resource]. Available at: http://russian.china.org.cn/exclusive/txt/2017-05/27/content40906 262.htm (Accessed: 27 May 2017).

[19] V. L. Erokhin and G. Tianmin, "Investitsionnoe sotrudnichestvo Rossii i Kitaia v regione Arktiki", IAMAL SPG i drugie perspektivnye proekty, Sbornik statei Mezhdunarodnoi nauchno-prakticheskoi konferentsii Sotrudnichestvo Kitaia i Rossii v ramkakh initsiativy Odin poias odin put, 11 September, 2017, pp. 6-16.

[20] N.A. Pegin, "Transportnyi potentsial Severnogo morskogo puti: status i perspektivy formirovaniia mezhdunarodnogo opornogo porta-khaba $\mathrm{v}$ Petropavlovskom-Kamchatskom", Sbornik dokladov foruma Arktika nastoiashchee i budushchee, SPb,4-6 December, 2017, pp. 25-26.

[21] A. Vedeneeva, O. Nikitina, and D Kozlov, "Mintrans opisal Sevmorput do 2024 goda", Vedomstvo sostavilo plan razvitiia Arktiki [Electronic resource]. Available at: https://www.kommersant.ru/doc/3799581.

[22] M. Liu and J. Kronbak, "The potential economic viability of using the Northern Sea Route(NSR) as an alternative route between Asia and Europe", Journal of Transport Geography, 2015, vol. 18, no. 3, pp.434 444.

[23] N. D. Mulherin, "The Northern Sea Route: Its development and evolving state of operations in 2020s", CRREL Report, 2015, vol. 96, no. 3 . 